\title{
Damian PIERZAK
}

Uniwersytet Śląski

\section{AGNIESZKA DZIUBA, KLODIA METELLI. LITERACKI PORTRET PATRYCJUSZKI, WYDAWNICTWO KUL, LUBLIN 2016, SS. 320 [RECENZJA]}

\author{
AGNIESZKA DZIUBA, CLODIA METELLI. A LITERARY PORTRAYAL OF \\ A PATRICIAN WOMAN, LUBLIN 2016, PP. 320 [REVIEW]
}

\begin{abstract}
The recent book by Agnieszka Dziuba will be appreciated by both the ancient historians and the classical scholars in Poland for, as a monograph of a Roman woman, it has no antecedent. The study concerns Clodia's background ("Clodia in historiography"), her portrayal by Cicero in the speech In Defense of M. Caelius Rufus, and her depiction in Catullus' poetry. In the latter case, the author had to assume that in some of the poems Lesbia can be identified with Clodia Metelli. Despite some minor misrepresentations and misprints, the book is a sound analysis of the literary texts featuring the eponymous character. In addition, it offers a lively picture of the role women played in the Roman aristocratic society.
\end{abstract}

Keywords: Clodia Metelli, Cicero, Catullus, biography, invective.

W przypadku wielu postaci starożytnych, które uchodzą za historyczne, nie może być mowy o obiektywnej biografii, wolnej od hipotez i domysłów. Dzieje się tak dlatego, że źródła, którym zawdzięczamy informacje na ich temat, są bardzo często wrogie, krytyczne albo uprzedzone w stosunku do opisywanych osób i zdarzeń. W takiej sytuacji przedmiotem badań powinna być nie tyle sama postać, ile jej literacki konstrukt, stanowiący wyłącznie zniekształcone odbicie rzeczywistości. Innym istotnym czynnikiem, obok intencji autora, odciskającym swoje piętno na powstającym w ten sposób obrazie, jest konwencja gatunkowa. Klodia Metelli to nie tylko przykład postaci, której charakter i cechy zarówno fizyczne jak i intelektualne trudno dzisiaj sprawiedliwie ocenić. Skoro bowiem poza karykaturą przedstawioną przez Cycerona w mowie Pro Caelio posiadamy wyłącznie drobne wzmianki na jej temat w jego listach oraz u innych autorów, właściwie jest ona w równej mierze postacią literacką. Agnieszka Dziuba [dalej A.D.] podjęła się 
trudnego, ale ważnego zadania odtworzenia wizerunku tej intrygującej kobiety, jaki wyłania się z tekstów antycznych, decydując się ponadto na uwzględnienie w swojej książce poezji Katullusa, co wymagało założenia, że Lesbia i Klodia Metelli przynajmniej w niektórych utworach są tożsame. Autorka czyni to w sposób bardzo ostrożny, świadoma, że nie można mieć pewności w tym względzie.

A.D. podkreśla na wstępie, że opis tytułowej bohaterki Jej książki w istniejących opracowaniach jest zazwyczaj stereotypowy i cechuje go brak obiektywizmu - charakterystyczny dla nauki dziewiętnastowiecznej. Próbę rekonstrukcji życiorysu rzeczywiście istniejącej patrycjuszki podjęła ostatnio Marylin B. Skinner (2011), w związku z czym Klodia Metelli... ma być przede wszystkim studium poświęconym portretowi literackiemu. Zamiarem Autorki była konfrontacja wizerunku tradycyjnej rzymskiej matrony okresu późnej republiki z obrazem moralnie zepsutej i niepoprawnej arystokratki, zachowanym dla potomności w pismach Cycerona i Katullusa. Książka w tym zakresie dobrze spełnia swoje zadanie, będąc jednocześnie jedyną na polskim rynku monografią Rzymianki sensu largo ${ }^{1}$. Dostarcza ponadto wielu cennych informacji na temat życia społecznego w starożytnym Rzymie oraz literatury późnorepublikańskiej, zwłaszcza retoryki. Nie jest jednak wolna od pewnych uogólnień oraz uchybień formalnych, niemniej wrażenie takie musi odnieść każdy, kto czyta studium poświęcone postaci, która budzi kontrowersje od starożytności po dzień dzisiejszy. Poniżej, streszczając poszczególne partie monografii, będę się odnosił głównie do opinii, z którymi się nie zgadzam. Nie znaczy to jednak, że mój odbiór książki jako całości jest negatywny. Wręcz przeciwnie, uważam, że będzie to obowiązkowa lektura każdego filologa zajmującego się republiką rzymską.

Pierwszy rozdział (s. 21-48) poświęcony został rzymskiej matronie i służy przede wszystkim jako tło dla dalszych rozważań. Musimy pamiętać, że Klodia opisywana w dwóch zasadniczych rozdziałach, trzecim i czwartym, to córka konsula z wybitnego rodu Klaudiuszy oraz wdowa po konsulu z innej wpływowej rodziny - Cecyliuszy Metellusów. Do najważniejszych cnót tak usytuowanej społecznie Rzymianki, jak zauważa Autorka, należały pietas (należny szacunek wobec męskich członków rodziny), pudicitia (skromność), castitas (czystość) oraz parsimonia (oszczędność). Kobieta powinna żyć skromnie i nie dawać otoczeniu powodów do plotek na swój temat. W dalszej części pracy A.D. dowodzi, że zamiarem Cycerona było przedstawienie wizerunku, który nie wpisywał się w powyższy schemat kobiecego zachowania. Musiał jednak czynić to w sposób zawoalowany, bowiem nie wypadało mu, nawet w ramach szeroko pojętej inwektywy, dopuścić się bezpośredniego ataku na rzymską matronę tej rangi.

Kolejny rozdział, „Klodia w historiografii” (s. 49-118), którego znaczna część (s. 49-87) odnosi się do znanych nam reprezentantów rodu Klaudiuszy, nie jest moim zdaniem w równym stopniu przekonujący. Autorka sama przyznaje,

${ }^{1}$ Sama Autorka podkreśla, że jak dotąd do naszej dyspozycji pozostawała wyłącznie książka o charakterze popularnonaukowym (Bieżuńska-Małowist, 1993). 
że „dzieje jej [sc. Klodii] rodu zostaną przedstawione w oparciu o najbardziej kompletny literacki tekst historyczny, a mianowicie $A b$ urbe condita Liwiusza, powstały za panowania Augusta, ale korzystający z wcześniejszej tradycji historiograficznej" (s. 49). Już na stronie następnej jednak przywołuje wyniki badań Timothy'ego P. Wisemana $(1979=2003)$, który dowiódl, że , «czarna legenda» Klaudiuszów narodziła się bądź w późnych latach pięćdziesiątych, bądź wczesnych latach czterdziestych [...]" z inicjatywy wrogiego im annalisty - Waleriusza Antiasa (s. 50). Teksty omawiane przez Autorkę w zasadniczej partii monografii są więc nie tylko wcześniejsze niż Liwiusz, ale poprzedzają również działalność historyka, na którym ten się opierał. Najpewniej więc „czarnej legendy” nie znał Katullus, a Cyceron nie miał po śmierci Klodiusza już okazji się do niej odnieść. $\mathrm{Z}$ takiego sposobu odbioru tekstów antycznych rodzą się pewne niekonsekwencje. Na s. 77, na przykład, czytamy, że Appiusz Klaudiusz (cos. 54) „zapisał się w historii jako typowy Klaudiusz", co wynikałoby z jego aroganckiego i skorumpowanego stylu życia. Na s. 198 natomiast zdanie następujące: „Mówca konsekwentnie wspomina o rodzie, z którego wywodziła się Klodia Metelli, z wielkim szacunkiem i uznaniem dla jego zasług. Nie wspomina o żadnych powodach do wstydu, co potwierdzałoby opinię Petera Wisemana [...]". Według słusznej zresztą teorii tego ostatniego, najstarszy z braci Klodii nie mógł być „typowym” Klaudiuszem, jeśli bierzemy pod uwagę obraz tego rodu, jaki kreśli Liwiusz. Wręcz przeciwnie - to zachowanie takich jak on w czasach określanych mianem schyłku republiki, a zwłaszcza jego brata Publiusza, doprowadziło do powstania tego wizerunku. Opisy zawarte w dziejach $A b$ urbe condita byłyby relewantne tylko przy założeniu, że rację miał Wellejusz Paterkulus, pisząc (II 9, 6) (Velleius, ed. Stegmann de Pritzwald 1965): „vetustior Sisenna fuit Caelius, aequalis Sisennae Rutilius Claudiusque Quadrigarius et Valerius Antias". Wiseman jednak udowodnił, że nie należy datować działalności Waleriusza Antiasa na lata 80. bądź 70. I w. p.n.e. (Wiseman, $1979=2003: 113,120-121)^{2}$.

Istotna jest jednak druga część tego rozdziału (s. 88-118), dotycząca już tytułowej bohaterki monografii, napisana z filologiczną akrybią oraz w sposób niezwykle obiektywny. Nieraz zresztą Autorka zwraca uwagę, że przedmiot badań historyka literatury nie powinien być przezeń oceniany stronniczo, co oczywiście nie wyklucza pasji badawczej. Sama przy tym doskonale realizuje swój postulat. Informacje na temat historycznej Klodii czerpiemy przede wszystkim z korespondencji Cycerona, której treść nie zawsze pozwala na wyciągnięcie wniosku, że mamy do czynienia z żoną Metellusa Celera, a nie którą́ z jej sióstr (wszystkie trzy przemianowały się z Claudia na Clodia na znak solidarności z bratem). Zdaniem A.D., niewiele faktów z jej życia, być może poza koneksjami rodzinnymi, da się obiektywnie ustalić. Podobnie jak część pośród nowożytnych badaczy uważa Ona, że informacja Plutarcha o rzekomych planach małżeńskich Klodii wobec M. Tulliusza jest nie-

\footnotetext{
${ }^{2} C f$. Lewandowski, 2007: 72-73.
} 
wiarygodna. Odrzuca natomiast opinie tych uczonych, którzy opisują Klodię jako kobietę niezwykle wykształconą i o wytwornym smaku literackim. Jej zdaniem nie znajdują one odzwierciedlenia w źródłach, ponieważ młodość tytułowej Rzymianki przypadła na niezwykle burzliwe czasy dla jej rodu. Ponadto, ze względu na trudną sytuację materialną, nie odebrała prawdopodobnie starannego wykształcenia.

Trzeci, najobszerniejszy rozdział pracy, rozpoczyna Autorka, wprowadzając czytelników w podstawowe zagadnienia dotyczące procesu Marka Celiusza Rufusa. Ta część książki (s. 127-158) ma więc charakter odtwórczy, ponieważ zamiarem A.D. nie była ogólna rewizja dotychczasowych ustaleń nauki nowożytnej na temat mowy Pro Caelio. Niektóre problemy badawcze podejmowane w monografii wymagały jednak zajęcia stanowiska w kwestiach, co do których do dzisiaj nie panuje zgoda wśród badaczy. Tak jest chociażby w przypadku romansu Celiusza i Klodii. A.D. opowiada się za poglądem przeważającym, tj. że pomiędzy tymi dwojgiem rzeczywiście miała miejsce bliższa relacja, a następnie doszło do zerwania stosunków. Tym samym w kolejnym rozdziale (s. 231 i n., 253-256) Celiusz z utworu 58 Katullusa (Caeli, Lesbia nostra, Lesbia illa ...) zostaje stosunkowo beztrosko zidentyfikowany z M. Celiuszem Rufusem, a Lesbia z żoną Metellusa Celera, podczas gdy takie rozumienie tego wiersza bynajmniej nie jest oczywiste ${ }^{3}$. Zwolennikiem odmiennej interpretacji - według której romans to wymysł Cycerona - jest Wilfried Stroh, którego argumenty jednak Autorka uznaje za „mało przekonujące” (s. 150, przyp. 84$)^{4}$. Uważam, że nie należało ograniczać tej kwestii, rzutującej w wielkim stopniu na całościowy obraz Klodii Metelli, do krótkiej wzmianki w przypisie. Moje własne zdanie w tej sprawie przedstawię nieco szerzej poniżej.

W podrozdziale zatytułowanym „Clodia meretrix” (s. 163-179) otrzymujemy właściwe rozwinięcie uwag dotyczących rzymskiej matrony. A.D. wyróżnia w strategii retorycznej Cycerona dwie najważniejsze przesłanki: po pierwsze - przestrzeganie zasad, jakie obyczaj przodków (mos maiorum) narzucał w relacjach z dobrze urodzonymi i wpływowymi Rzymiankami; po drugie - odmalowanie swojej rywalki w jak najczarniejszych barwach. Mówca osiąga swoje zamierzenia dzięki wykorzystywaniu dwuznaczności niektórych sformułowań oraz przedstawianiu wizerunku prostytutki ${ }^{5} \mathrm{~W}$ odniesieniu do jakiejś hipotetycznej kobiety, nie zaś obecnej na rozprawie patrycjuszki.

${ }^{3}$ Cf. Kroll, 1960: 103. ,[...] gerichtet an einen Freund, in dem man zunächst den Caelius aus Verona (c. 100) erblicken wird" oraz von Albrecht, 2012: 285-286.

${ }^{4}$ Austin (1960: vi-vii oraz „Appendix III”), na którego wydaniu Autorka opiera swoje rozważania, omawia to zagadnienie bardziej szczegółowo.

${ }^{5}$ Autorka, aby podkreślić wagę stosowanych przez Cycerona obelg, konsekwentnie posługuje się wyrazem dziwka. Rzeczownik ten jednak budzi, moim zdaniem, skojarzenia z wulgaryzmem, który obecnie już niekoniecznie oznacza kobietę lekkich obyczajów. Słownik łacińsko-polski pod red. J. Korpantego podaje (s.v. meretrix): „prostytutka, nierządnica, hetera, kurtyzana, utrzymanka”. Nawiasem mówiąc, odnosi się wrażenie, że w odpowiedzi na pewien „ugrzeczniony” sposób thumaczenia tekstów antycznych (Katullus jest chyba najlepszym przykładem) mamy dzisiaj często do czynienia z trendem odwrotnym. 
Nawiązanie Cycerona do Medei (,Medea Palatina”, s. 179-190) odczytuje Autorka przede wszystkim jako sposób nadania przeciwniczce cech pożądliwej (mulier libidinosa), porzuconej kochanki. W tej trudnej, szeroko w literaturze przedmiotu komentowanej partii tekstu, A.D. tylko do pewnego stopnia zgadza się ze Skinner, pisząc (s. 180): ,interpretacja metafor zastosowanych przez obu mówców jest niespójna". Przypomnijmy, że chodzi tu o miejsce, gdzie Cyceron cytuje parę wersów tragedii Medea exul Enniusza, z których co najmniej jeden (Utinam ne in nemore Pelio-) przytoczył wcześniej M. Licyniusz Krassus. W tej aluzyjnej grze czynny udział brały więc przynajmniej cztery osoby (poza wymienionymi również Atratynus oraz sam oskarżony). $\mathrm{Z}$ innych źródeł wiemy, że oskarżyciel nazwał Celiusza „delikatnym Jazonem” (pulchellum Iasonem [RLM, s. 124 Halm $={ }^{2} O R F$, s. 513, ed. Malcovati 1955]), natomiast Celiusz nazwał kogoś „Peliasem o kędzierzawych włosach" (Quint. Inst. I 5, $61={ }^{2} O R F$, s. 488: Pelia cincinnatus). Z tekstu mowy rzeczywiście wynika, że obiektem aluzji Krassusa był król Ptolemeusz. Mało prawdopodobne wydaje mi się jednak, że jego zamiarem było zestawienie go z Jazonem, sugerujące, iż zdobycie pomocy Rzymu było dla niego równie trudne ,jak dla Jazona złote runo".

Najpewniej to Atratynus rozpoczął tę metaforyczną wymianę, nazywając Jazonem Celiusza i zwracając tym samym uwagę na jego rozrzutny tryb życia. Oskarżony potrzebowałby złotego runa, aby opłacić swoje zachcianki. W odpowiedzi na to Celiusz nazwał Peliasem nie jego, ale jednego z oskarżycieli pomocniczych (subscriptor), L. Herenniusza Balbusa. W takim zestawieniu wiek znaczonego bardziej odpowiadałby wiekowi znaczacego. Poza tym i on pragnął zguby „Jazona”, a ponadto Cyceron opisuje go jako pertristis patruus quidam (Cael. 25) (Cicero, ed. Austin, 1960) ${ }^{6}$. Pierwotnie więc aluzje te dotyczyły wyłącznie celu wyprawy Argonautów oraz relacji pomiędzy mitycznym wujem a bratankiem. Wówczas dopiero Krassus zacytował urywek prologu wypowiadanego przez piastunkę. Wersy te jednak w pierwszym rzędzie odnoszą się do Medei. Oboje - ona i król Ptolemeusz - najpierw oferowali złoto i otrzymali ochronę, a następnie zostali porzuceni. Wreszcie Cyceron, odpowiednio manipulując wersami Enniusza, przeniósł metaforykę mitologiczną na grunt „Jazon - Medea”. Według takiej interpretacji należałoby zgodzić się z tezą Stroha, iż romans Celiusza i Klodii był wymysłem mówcy, obliczonym na wykorzystanie topiki porzuconej, mściwej kochanki, która doskonale wpisywała się również w teatralny wydźwięk całej mowy (Stroh, 1975: 276-277)7. Urywek ten z pewnością wymaga dokładniejszej analizy, na którą nie ma miejsca w tekście recenzji, niemniej powyższy przyczynek powinien pokazać, że również kwestia, czy romans pomiędzy Klodią Metelli

${ }^{6}$ Cf. Volpe, 1977: 317-318. Cyt. za: Alexander, 2002: 321, przyp. 33. Volpe podaje jednak Atratyna jako obiekt riposty.

7 Tezę Stroha zaakceptował m.in. Schmitz (1985: 117-118). Cf. Münzer 1909: 136, przyp. 3. Więcej na ten temat można przeczytać w Pierzak, 2015a: 62-64 oraz w maszynopisie mojej rozprawy doktorskiej, Pierzak 2015b: 193-199. 
a Celiuszem rzeczywiście miał miejsce, wymaga szerszego komentarza, nawet jeśli fakt ten nie ma wielkiego wpływu na literacki portret patrycjuszki.

Kolejny podrozdział, pt. „Domus Clodiae” (s. 190-210), uzupełnia poniekąd deskrypcję Klodii jako anty-matrony rzymskiej. Motyw domu, często pojawiający się w mowie również w odniesieniu do innych uczestników procesu (samego oskarżonego, jego ojca, Krassusa, Cycerona, etc.), został przebadany przez Autorkę z punktu widzenia jego szerokich konotacji społeczno-obyczajowych. Siedziba rodu bowiem, jego mieszkańcy i panujące w nim zwyczaje odzwierciedlały moralną postawę pater oraz mater familias. Opisywane przez mówcę hulanki, młodzi mężczyźni przybywający na orgie i wszelkiego rodzaju inne ekscesy, o których donosi, pozwalały dodatkowo zdyskredytować głównego świadka oskarżenia. Także tu, jak dowodzi A.D., musiał się Arpinata uciekać do ataków pośrednich, kierowanych przecież przeciwko kobiecie, której z racji statusu społecznego należał się szacunek.

Ostatnia sekcja tej części rozprawy podejmuje natomiast wątki „teatralne”, tym razem jednak wywołujące skojarzenia z komedią oraz mimem (s. 210-226). Dogłębnej analizie poddana została zwłaszcza scena rzekomego przekazania trucizny, którą Klodii mieli podać jej niewolnicy. Cyceron wykorzystał szczególne okoliczności procesu, odbywającego się w tym samym czasie co ludi Megalenses, w związku z czym zarówno sędziowie jak i słuchacze nie mogli uczestniczyć w zwyczajowo wówczas organizowanych przedstawieniach teatralnych. Autorka podkreśla (s. 209), że owa „teatralizacja” mowy Pro Caelio to temat szeroko komentowany w literaturze przedmiotu, dlatego też nie omawia wszystkich zagadnień z nią związanych. Choć kolejność podrozdziałów składających się na tę część książki odpowiada wymogom varietas, której hołdowali poeci antyczni, wydaje się, że gdyby zamienić miejscami punkty 4.2 (Medea Palatina) oraz 4.3 (Domus Clodiae) literacki obraz byłby bardziej przejrzysty. Otrzymalibyśmy wówczas najpierw opis zdemoralizowanej matrony rzymskiej, a następnie obraz utkany z aluzji teatralnych - odpowiednio tragicznych i komicznych (jeśli komedię uzupełnić o mim $)^{8}$.

Druga zasadnicza część monografii przedstawia sylwetkę Klodii Metelli w twórczości Katullusa. Dopóki nie odnajdą się jakieś dodatkowe świadectwa na ten temat, problem identyfikacji Lesbii z Klodią Metelli jest właściwie nierozwiązywalny. Opiera się bowiem wyłącznie na skąpej informacji Apulejusza z Madaury (Apol. 10: „eadem igitur opera accusent C. Catul $<l>$ um, quod Lesbiam pro Clodia nominarit [...]") (Apuleius, ed. Helm, 1972), nie precyzującego, którą z sióstr ma na myśli oraz na założeniu pewnych uczonych nowożytnych (s. 228), że Lesbia to Klodia osławiona za sprawą głośnego procesu Celiusza. Zarówno jednak „protagonistka” mowy Pro Caelio jak i „Lesbia”, co

8 Cf. słynne Cic. Cael. 65 ad fin.: „Mimi ergo iam exitus, non fabulae; in quo cum clausula non invenitur, fugit aliquis e manibus, dein scabilla concrepant, aulaeum tollitur" (Cicero, ed. Austin, 1960). 
niejednokrotnie odnotowuje Autorka, to przede wszystkim twory literackie, wpisujące się w odpowiednie konwencje gatunkowe. Dlatego też słusznie nie zakłada Ona a priori identyfikacji rzeczywiście istniejącej patrycjuszki z obiektem westchnień poety z Werony. Słowa ze s. 275 są dobrym podsumowaniem badań przeprowadzonych przez A.D. w tej partii książki: „Przedstawiona powyżej analiza heteroerotycznych wierszy Katullusa w kontekście próby identyfikacji poetyckiej bohaterki z historyczną Klodią Metelli nasuwa więcej wątpliwości niż ich rozwiązuje. [...] Powyższe spostrzeżenia nie wykluczają co prawda identyfikacji Lesbii z Klodią Metelli, jednakże każą w poetyckim portrecie dostrzegać elementy licentia poetica".

Trudno odmówić także i tu wywodom Autorki wnikliwości, jednak daje się dostrzec pewna dysproporcja pomiędzy częścią poświęconą Cyceronowi oraz tą dotyczącą poezji ${ }^{9}$. Być może należy to tłumaczyć faktem, że „Lesbia” jest Klodią Metelli wyłącznie hipotetycznie, w związku z czym nawet jako element portretu literackiego nie zasługuje na uwagę $\mathrm{w}$ tym samym stopniu, co jej odpowiedniczka z mowy i korespondencji Arpinaty.

Z uwag zamieszczonych w ,Zakończeniu” wynika, że zamierzeniem Autorki było po pierwsze opracowanie, które stanowiłoby złoty środek pomiędzy stereotypowym odczytaniem obrazu Klodii jako kobiety zepsutej, inspirowanym głównie artykułem w RE Friedricha Münzera, a interpretacjami genderowymi, chcącymi widzieć w niej „wykształconą erudytkę, zaangażowaną w politykę, kobietę wyzwoloną" (s. 286). Po drugie, A.D. odrzuca optymistyczne przesłanki Skinner, która w labiryncie literackich odniesień i aluzji usiłowała dotrzeć do historycznej prawdy. Praca ta zatem jest na wskroś literaturoznawcza zarówno z założenia jak i w praktyce, jednak trzeba raz jeszcze podkreślić, że akcent spoczywa tu, kosztem poezji, na retoryce. Książkę kończy ważne pytanie o „kulturowy fenomen Klodii Metelli, o to, jak doszło do tego, że postać literacka stała się postacią historyczną?". Miejmy nadzieję, że ktoś (być może sama Autorka?) spróbuje w najbliższej przyszłości na to pytanie odpowiedzieć.

Wypada jeszcze zwrócić uwagę na kilka dyskusyjnych kwestii szczegółowych. Na s. 122 , przyp. 8 Autorka błędnie interpretuje wyraz invectiva, ,jako metaforyczne pluralis neutrum urobione od znanego w czasach Arpinaty czasownika inveho - najechać w celu ataku". Rzeczywiście jest to przymiotnik urobiony od podanego czasownika, niemniej raczej femininum singulare niż ,pluralis neutrum", ponieważ już przywołany w cytowanym miejscu Ammianus Marcellinus (XXI 10, 7) używa go, określając rzeczownik oratio (Koster, 1980: 1, przyp. 2; Novokhatko, 2009: 12). W przeciwnym razie również po polsku musielibyśmy mówić, że są to „te inwektywa”, a nie jest „ta inwektywa”.

9 Zabrakło zwłaszcza nowszych komentarzy poezji Katullusa, w tym chyba najobszerniejszego (Syndikus, 1984, 1987, 1990). W dużej mierze natomiast opiera się A.D. na wydanym niedawno nowym polskim przekładzie Grzegorza Franczaka i Aleksandry Klęczar, opracowanym przez tę ostatnią (Kraków 2013). 
Na s. 136 należałoby inaczej przetłumaczyć Quint. Inst. X 1, 115: „Multum ingenii in Caelio et praecipue in accusando multa urbanitas, dignusque vir, cui et mens et vita longior contigisset" (Quintilianus, ed. Radermacher 1965), co A.D. oddaje następująco: „Celiusz odznaczał się wielkim talentem, a szczególnie wielkim dowcipem w oskarżaniu. Wybitny mąż, któremu mógłby się trafić i lepszy charakter, i dłuższe życie". Coniunctivus występuje tu w zdaniu względnym wyrażającym skutek po przymiotniku dignus. Można je więc rozumieć w przybliżeniu tak: „Człowiek godny tego, aby przypadło mu w udziale dłuższe, lepiej przemyślane życie"10.

Podobnie, na s. 248, Autorka proponuje, by thumaczyć Catul. 42, 13 („Non assis facis? [...]”) jako „nie zarabiasz?”, co wydaje mi się nie do przyjęcia. Assis aliquid facere to typowa konstrukcja z użyciem genetiwu pretii („mieć coś za nic, nisko coś cenić, etc.”). Nie sądzę też, że „koncept poetycki w treści [utworu 42 - D.P.] sprowadza się do odebrania napastliwych wierszy od dziewczyny [...]". Poeta wzywa wprawdzie jedenastozgłoskowce (hendecasyllabi) ale po to, aby pomogły mu odzyskać pugillaria (w. 5) - tabliczki, na których zapisywano drobne treści.

Zdarzają się również błędy literowe, zwłaszcza na gruncie cytatów łacińskich. Podam tylko kilka przykładów. Na s. 41 Cracchorum zamiast Gracchorum, na s. 74 Craccho zam. Graccho, na s. 119 similitude zam. similitudo, na s. 129 poene zam. paene, na s. 133 quo zam. quod, na s. 139 familiaritatis zam. familiaritas, na s. 141 antiquitem zam. antiquitatem, etc. W jednym miejscu jednak prowadzi to Autorkę do niewłaściwej interpretacji omawianego tekstu. Na s. $161 \mathrm{Cic}$. Cael. 18 zapisano w ten sposób: „Sic enim, iudices, reperietis quod, cum ad id loci veneno ostendam [...]”, co przetłumaczone zostało następująco: „Tak więc, sędziowie, odkryjecie, gdy przejdę w mowie do sprawy trucizny [...]" podczas gdy zamiast veneno należy czytać venero. Uzyskujemy wówczas proste zdanie czasowe wyrażające w futurum primum i exactum dwie czynności, które jedna po drugiej nastąpią w przyszłości: „gdy przejdę do tego miejsca, pokażę”. Trudno mi sobie wyobrazić, jaka zależność syntaktyczna musiałaby zaistnieć pomiędzy id loci a veneno, abyśmy mogli rozumieć tę wypowiedź tak jak A.D. Żadna z tych omyłek, może z wyjątkiem ostatniej, nie jest jednak poważna na tyle, by wprowadzić uważnego czytelnika w błąd.

Jeszcze jedna uwaga techniczna. Nie do końca rozumiem, dlaczego zdecydowano się na pełen opis bibliograficzny odniesień do autorów antycznych, np. M. [sic] Fabi Quintiliani Institutionis oratoriae libri XII, ed. L. Rademacher [sic], Leipzig 1965 w przypisie zamiast po prostu Quint. Inst. V 10, 23, które pojawia się w tekście głównym, skoro poszczególne wydania znajdują się ponownie w tej samej formie w bibliografii (s. 289-292).

${ }^{10}$ Cf. Cic. Brut. 71: „Livianae fabulae non satis dignae, quae iterum legantur” (Cicero, ed. Wilkins, 1970); Liv. XXX 30, 24: ,forsitan non indigni sumus, qui nobismet ipsi multam irrogemus” (Kühner-Stegmann, 1962: 302-303 [§ 194, 8 d]). Właściwą interpretację tego urywka ostatecznie zawdzięczam jednemu z Recenzentów Collectanea Philologica, któremu w tym miejscu pragnę podziękować. 
Pora na krótką konkluzję. Temat podjęty przez Autorkę, ze względu na niewielką ilość świadectw opisujących rzeczywista Klodię Metelli, zawsze będzie prowokował dyskusję, ponieważ zbyt wiele wątków wymaga tu subiektywnej oceny. Analizując dotychczasowe ustalenia uczonych, A.D. pokazała, że (literacki) obraz tytułowej bohaterki Jej książki zdominowany jest przez różne cechy kobiecego charakteru, przymioty i wady, w zależności od tego, po przyjęciu jakiej perspektywy badawczej zostanie utworzony. Choć brak niektórych opracowań oraz sposób wykorzystania innych budzi niekiedy wątpliwości, hipoteza badawcza oraz jej rozwinięcie są przekonujące, a lektura całości - nawet jeśli nie wszystkie podrozdziały wpisują się bez zastrzeżeń w podjętą problematykę - pouczająca. Dlatego też, jak sądzę, Klodia Metelli... pozostanie cennym kompendium wiedzy na temat miejsca kobiety w kręgach arystokratycznych starożytnego Rzymu i być może punktem wyjścia do dalszych w tym zakresie badań.

\section{Bibliografia}

Alexander, M. C. (2002). The Case for the Prosecution in the Ciceronian Era. Ann Arbor: The University of Michigan Press.

Austin, R. G. (ed.) (1960). M. Tulli Ciceronis Pro M. Caelio oratio. Oxford: Oxford University Press.

Bieżuńska-Małowist, I. (1993). Kobiety antyku. Talenty, ambicje, umiejętności. Warszawa: Wydawnictwo Naukowe PWN.

Helm, R. (ed.) (1972). Apulei Platonici Madaurensis Pro se de magia liber (apologia). Leipzig: B.G. Teubner.

Koster, S. (1980). Die Invektive in der griechischen und römischen Literatur. Meisenheim am Glan: Anton Hain.

Kroll, W. (ed.) (1960). C. Valerius Catullus. Stuttgart: B.G. Teubner.

Kühner, R., Stegmann, C. (1962). Ausführliche Grammatik der lateinischen Sprache. Satzlehre, zweiter Teil. München: Max Hueber.

Lewandowski, I. (2007). Historiografia rzymska. Poznań: Wydawnictwo Poznańskie.

Malcovati, H. (ed.) (1955). Oratorum Romanorum fragmenta liberae rei publicae. Torino: G.B. Paravia.

Münzer, F. (1909). Aus dem Leben des M. Caelius Rufus. „Hermes” 44. 135-142.

Novokhatko, A. A. (ed.) (2009). The Invectives of Sallust and Cicero. Berlin-New York: Walter de Gruyter.

Pierzak, D. (2015a). A Reading of Greek Myth in Cicero's Speeches. The Case of Medea. W: M. Budzowska, J. Czerwińska (eds.). Ancient Myths in the Making of Culture. Frankfurt a. M.: Peter Lang.

Pierzak, D. (2015b). Mit grecki w Mowach Cycerona. Diss. Katowice.

Radermacher, L. (ed.) (1965). M. Fabi Quintiliani Institutionis oratoriae libri XII. Lipsiae: B.G. Teubner.

Schmitz, D. (1985). Zeugen des Prozeßgegners in Gerichtsreden Ciceros. Frankfurt a. M.-BernNew York: Peter Lang.

Skinner, M. B. (2011). Clodia Metelli. The Tribune's Sister. Oxford-New York: Oxford University Press. 
Stegmann de Pritzwald, C. (ed.) (1965). C. Vellei Paterculi ex Historiae Romanae libris duobus quae supersunt. Stutgardiae: B.G. Teubner.

Stroh, W. (1975). Taxis und Taktik: die advokatische Dispositionskunst in Ciceros Gerichtsreden. Stuttgart: B.G. Teubner.

Syndikus, H. P. (1984). Catull. Eine Interpretation. Erster Teil: Einleitung, Die kleine Gedichte (1-60). Darmstadt: Wissenschaftliche Buchgesellschaft.

Syndikus, H. P. (1987). Catull. Eine Interpretation. Dritter Teil: Die Epigramme (69-116). Darmstadt: Wissenschaftliche Buchgesellschaft.

Syndikus H. P. (1990). Catull. Eine Interpretation. Zweiter Teil: Die Grossen Gedichte (61-68). Darmstadt: Wissenschaftliche Buchgesellschaft.

Volpe, M. (1977). The Persuasive Force of Humor: Cicero's Defense of Caelius. „Quarterly Journal of Speech". 63. 311-323.

von Albrecht, M. (2012). Geschichte der römischen Literatur. Berlin-Boston: De Gruyter.

Wilkins, A. S. (ed.) (1970). M. Tulli Ciceronis Rhetorica. T. II. Oxford: Oxford University Press.

Wiseman, T. P. (1979). Clio's Cosmetics. Three Studies in Greco-Roman Literature. Leicester: Leicester University Press, (przedruk: Bristol: Bristol Phoenix Press 2003). 